\title{
Sistem Pendukung Keputusan Menggunakan Certainty Factor Dalam Mendiagnosa Kategori Tingkat Demam Berdarah
}

\author{
Achmad Rizaldi Putra ${ }^{1}$, Apriade Voutama ${ }^{2}$, Susilawati ${ }^{3}$ \\ 1,2,3 Teknik Informatika, Fakultas Ilmu Komputer, Universitas Singaperbangsa Karawang \\ E-mail: *1achmad.rizaldi17033@student.unsika.ac.id, \\ 2apriade.voutama@staff.unsika.ac.id. ${ }^{3}$ susilawati.sobur@ staff.unsika.ac.id
}

\begin{abstract}
Abstrak - Dalam sektor kesehatan, penyakit Demam Berdarah atau yang sering disebut dengan DBD sampai dengan saat ini masih menjadi masalah besar kesehatan yang sungguh serius yang terjadi di berbagai dunia dan juga di Indonesia. Penyakit ini merupakan penyakit menular dan dapat menjangkit sетиа usia dikarenakan masih banyak dari masyarakat yang masih kurangnya kesadaran dalam menjaga kebersihan untuk mengantisipasi penularan. Data yang tertera pada Kementerian Kesehatan Republik Indonesia (Kemenkes RI) Indonesia mencatatkan jumlah masyarakat yang terjangkit penyakit Demam Berdarah sebanyak 95.893 sepanjang tahun 2020 dan sebanyak 661 orang meninggal akibat penyakit ini. Metode yang digunakan yaitu menggunakan metode certainty factor yang mana kalau diartikan metode ini nantinya digunakan untuk membantu mengambil sebuah keputusan untuk mendiagnosa kategori tingkat Demam Berdarah dengan tingkat keyakinan berupa persentase seberapa besar seseorang terjangkit Demam Berdarah pada kategori yang ada. Hasil yang didapat pada perhitungan certainty factor mendapatkan sebuah hasil pada kategori grade 1 sebesar 98\%, grade 2 sebesar 98\%, grade 3 sebesar 99\%, grade 4 sebesar 99\%. Hasil tersebut sudah cukup membuktikan bahwa metode certainty factor ini memiliki hasil tingkat persentase yang cukup tinggi.
\end{abstract}

Kata Kunci - Certainty Factor, Demam Berdarah, ESDLC (Expert System Development Cycle)

\begin{abstract}
In the health sector, Dengue Fever or what is a often referred as to DHF is still a big, serious health problem that occurs in various parts in the world and also in Indonesia. This disease is an infectious disease and can infect all ages because there are still many people who still lack awareness in maintaining cleanliness to anticipate transmission. Data contained in the Ministry of the Health Republic of Indonesia (Kemenkes RI) Indonesia recorded the number of people infected with Dengue Fever disease as many as 95,893 throughout 2020 and as many as 661 people died from this disease. The method is used using the certainty factor method, which means that this method will be used to help make a decision to diagnose the category of Dengue Fever level with a level of confidence in the form of a percentage of how large a person is infected with Dengue Fever in the existing category. The results obtained in the calculation of certainty factor get a result in the category of grade 1 of 98\%, grade 2 of 98\%, grade 3 of 99\%, grade 4 of 99\%. These results are enough to prove that this certainty factor method has a fairly high percentage level result.
\end{abstract}

Keywords - Certainty Factor, Dengue Fever, ESDLC (Expert System Development Cycle)

\section{PENDAHULUAN}

Ketergantungan akan teknologi yang mana semakin hari perkembangan nya semakin pesat dan kebutuhan informasi yang akurat begitu sangat penting terhadap perkembangan masyarakat dan sangat dibutuhkan pada saat ini [1]. Dikarenakan manfaat yang diberikan begitu besar untuk menciptakan efisiensi dan memudahkan guna membantu pekerjaan manusia dalam 
menyelesaikan suatu pekerjaan [2]. Sektor kesehatan merupakan salah satu dari sekian banyak sektor yang cukup merasakan banyak manfaat dari telah berkembangnya sebuah ilmu pengetahuan dan teknologi [3].

Terdapat 34 provinsi yang tersebar di 472 Kabupaten/Kota yang menjadi daerah penyebaran atau mencatatkan kasus Demam Berdarah dan sebanyak 95.893 orang tercatat terjangkit penyakit Demam Berdarah dengan kasus kematian akibat penyakit Demam Berdarah sebanyak 661 orang yang dihimpun dari Kementerian Kesehatan Republik Indonesia (Kemenkes RI) [4].

Langkah awal yang pastinya harus dilakukan sebelum membuat sistem pendukung keputusan diantaranya ialah menentukan analisis masalah dan analisis kebutuhan [5]. Analisis masalah berguna untuk dapat menentukan masalah yang terjadi pada saat ini apakah permasalahan yang ada memang masalah yang cukup serius dan harus segela ditemukan solusinya atu tidak [6]. Analisis kebutuhan berguna untuk bisa menetapkan hal apa saja yang akan diperlukan nantinya ketika akan membangun suatu sistem pendukung keputusan setelah dilakukan analisis masalah [7].

Tingkatan dari penyakit Demam Berdarah ini pun beragam dan cara penanganan dari tiap-tiap tingkatan pun berbeda yang dapat dikelompokkan menjadi 4 kelompok, diantaranya Grade 1 yang dapat ditangani dirumah dengan banyak mengkonsumsi air mineral yang banyak, Grade 2 yang dapat ditangani dengan diberikan obat paracetamol apabila panas pada badan tidak kunjung turun, Grade 3 yang dapat ditangani dengan penanganan lebih lanjut di rumah sakit dengan pemberiak cairan invus, Grade 4 yang mempunyai kriteria pasien berstatus waspada [8].

Dari beberapa penelitian yang pernah dilakukan peneliti sebelumnya yang membuat sistem pendukung keputusan mendiagnosa penyakit Demam Berdarah menggunakan algoritma Iterative Dichotosimer 3 (ID3) memperoleh hasil tingkat akurasi sebesar 75,253\% [9]. Penelitian selanjutnya yang membuat sistem pendukung keputusan diagnosa Demam Berdarah menggunakan metode Forward Chaining memperoleh hasil tingkat akurasi sebesar 48,63\% [10]. Kemudian pada penelitian selanjutnya menggunakan algoritma Backward Chaining dan hanya mendiagnosa awal demam berdarah [11]. Pada penelitian sebelumnya hanya membuat sistem pendukung keputusan untuk diagnosa awal demam berdarah saja.

Oleh karena itu, berdasarkan beberapa penelitian yang pernah dilakukan sebelumnya terdapat perbedaan algoritma yang digunakan dengan penelitian saat ini, maka pada penelitian ini akan membangun sebuah sistem pendukung keputusan untuk mendiagnosa kategori tingkat demam berdarah menggunakan metode certainty factor dan metodologi ESDLC (Expert System Development Cycle) untuk menyelesaikan permasalahan yang ada. Pada penelitian sebelumnya platform yang digunakan hampir sebagian besar menggunakan platform android, sedangkan pada penelitian ini platform yang digunakan yaitu berbasis website.

\section{METODE PENELITIAN}

\subsection{Metode Certainty Factor}

Metode certainty factor (CF) atau yang tidak jarang dikenal sebagai faktor kepastian ialah metode yang dimanfaatkan pada penelitian ini yang dikenalkan oleh Shortliffe Buchanan yang dipakai untuk dapat mengukur besarnya sebuah tingkat kepercayaan dalam pengambilan suatu keputusan [12]. Seorang berpengalaman atau ahli dalam urusan ini umumnya dokter/ahli kerap kali menjabarkan informasi yang terdapat dengan pengandaian misalnya "mungkin", "kemungkinan besar" \& "hampir pasti" [13]. Ada dua faktor yang mengakibatkan hasil yang menyebabkan ketidakpastian terhadap suatu pertanyaan yang diberikan oleh sistem terhadap pakar, yang pertama yaitu rule/aturan yang tidak tentu dan yang kedua adalah jawaban dari user/pemakai yang tidak tentu [14]. 


\section{Metode Net Belief}

Metode ini ialah metode yang dikenalkan oleh E.H. Shortlife dan juga B.G. Buchanan dengan rumus : $\mathrm{CF}($ Rule $)=\mathrm{MB}(\mathrm{H}, \mathrm{E})-\mathrm{MD}(\mathrm{H}, \mathrm{E})[15]$.

$$
\begin{aligned}
& M B(H, E)=\left\{\frac{\max [P(H \mid E), P(H)]-P(H)}{\max [1,0]-P(H)}\right\} P(H)=1, \text { lainnya } \\
& M D(H, E)=\left\{\frac{\min [P(H \mid E), P(H)]-P(H)}{\min [1,0]-P(H)}\right\} P(H)=0, \text { lainnya }
\end{aligned}
$$

Bisa diketahui $\mathrm{CF}($ Rule) itu sendiri ialah faktor kepastian, $\mathrm{MB}(\mathrm{H}, \mathrm{E})$ itu sendiri ialah tingkat kepercayaan terhadap hipotesis $\mathrm{H}$ jika diberikan $\mathrm{E}$ (Evidence) antara 0 \& $1, \mathrm{MD}(\mathrm{H}, \mathrm{E})$ itu sendiri ialah tingkat ketidakpercayaan terhadap hipotesis $\mathrm{H}$ jika diberikan $\mathrm{E}$ (Evidence) antara 0 \& $1, \mathrm{P}(\mathrm{H})$ itu sendiri ialah probabilitas kebenaran hipotesis $\mathrm{H}$ dan $\mathrm{P}(\mathrm{H} \mid \mathrm{E})$ itu sendiri ialah probabilitas bahwa $\mathrm{H}$ benar dipengaruhi fakta $\mathrm{E}$.

\section{Perhitungan Certainty Factor Gabungan}

Secara garis besar, rule pada certainty factor gabungan dapat dinyatakan kedalam bentuk seperti berikut [16] :

IF E1 AND E2 ................ AND En THEN H (CF Rule)
IF E1 AND E2 …............. OR En THEN H (CF Rule)

Bisa diketahui E1 ...... E2 ialah fakta-fakta (Evidence) yang ada, $\mathrm{H}$ ialah Hipotesis atau Konklusi yang dihasilkan, CF Rule merupakan tingkat keyakinan terjadinya hipotesis $\mathrm{H}$ akibat adanya fakta-fakta.

\subsection{Metodologi ESDLC (Expert System Development Cycle)}

ESDLC (Expert System Development Cycle digunakan ketika ingin mengembangkan atau membangun sebuah sistem menggunakan referensi pendekatan secara konvensial. Pada penelitian ini peneliti hanya melakukan tahapan dari ESDLC hanya sampai pada tahap dokumentasi dikarenakan untuk tahap pemeliharaan dilakukan seiring berjalan nya waktu. Berikut adalah langkah-langkah atau tahapan dari ESDLC [17] :

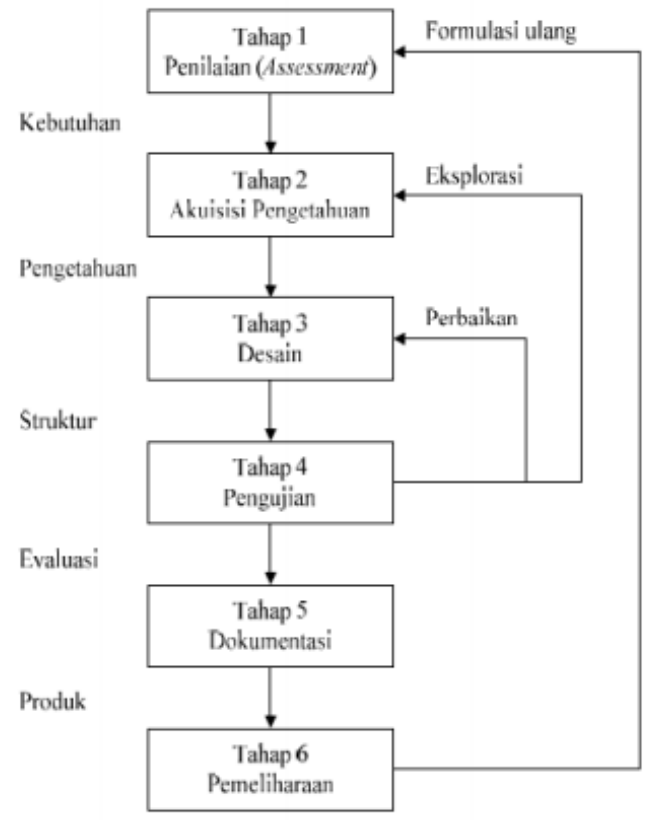

Gambar 1. Tahapan ESDLC (Expert System Development Cycle) 
1. Penilaian (Assessment)

Tahapan ini ialah tahapan untuk menentukan kelayakan atau tidaknya sebuah sistem akan dikembangkan [18].

2. $\quad$ Akuisisi Pengetahuan (Knowledge Acquisition)

Tahapan ini ialah tahapan untuk mencari atau mendapatkan sebuah pengetahuan yang dibutuhkan sebagai bahan untuk pembuatan sistem [18].

3. Desain (Design)

Tahapan ini ialah tahapan dimana sistem yang nantinya akan dibuat, dirancang terlebih dahulu [19].

4. Pengujian (Test)

Tahapan ini ialah tahapan yang bertujuan untuk menguji sebuah sistem yang sudah dibuat untuk memastikan apakah sudah sesuai atau belum [20].

5. Dokumentasi (Documentation)

Tahapan ini ialah tahapan dimana ketika sistem sudah dibuat dioperasikan atau digunakan.

\section{HASIL DAN PEMBAHASAN}

Dalam penelitian pembuatan sistem keputusan ini data yang dimanfaatkan ialah data yang dikumpulkan melalui proses wawancara atau tanya jawab secara langsung terhadap pakar yang berisi data gejala, nilai keyakinan, representasi pengetahuan, relasi gejala dengan tingkatan.

\subsection{Penilaian (Assessment)}

Penilaian ini dilakukan dengan cara mengidentifikasi masalah serta analisis kebutuhan untuk menunjang pembuatan sistem. Penilaian ini dilakukan dengan 2 cara yaitu analisis masalah dan kebutuhan. Analisis masalah yang terjadi pada saat ini ialah masih minimnya sebuah sistem yang bisa melakukan diagnosis terhadap sebuah penyakit untuk membantu pengambilan sebuah keputusan. Analisis kebutuhan pada penelitian ini ialah kebutuhan akan alat yang dapat memberikan pengetahuan, sistem yang dapat digunakan dan menjadi alternatif pakar dalam mendiagnosa Demam Berdarah.

\subsection{Akuisisi Pengetahuan}

Tahapan ini ialah tahapan mencari informasi yang berkaitan dengan penelitian yang dibagi kedalam 3 bagian, diantaranya pengumpulan data, representasi pengetahuan, certainty factor.

\section{Pengumpulan Data}

Berdasarkan hasil wawancara langsung dengan pakar dapat diperoleh data 4 tingkatan penyakit Demam Berdarah yang bisa diperhatikan pada Tabel 1 seperti berikut.

\section{Tabel 1. Tingkatan Demam Berdarah dan Kode}

\begin{tabular}{cc}
\hline \hline Kode & Tingkatan \\
\hline GR1 & Grade 1 \\
GR2 & Grade 2 \\
GR3 & Grade 3 \\
GR4 & Grade 4
\end{tabular}

Terdapat sejumlah gejala yang umum dialami oleh penderita penyakit Demam Berdarah, gejala ini diperoleh dari hasil wawancara langsung kepada pakar kemudian dari tiap gejala tersebut diberikan sebuah kode agar dapat memudahkan dalam pembuatan rule yang bisa diperhatikan pada Tabel 2 seperti berikut. 
Tabel 2. Gejala Pada Demam Berdarah

\begin{tabular}{cl}
\hline \hline Kode & \multicolumn{1}{c}{ Nama Gejala } \\
\hline G01 & Demam Tinggi Lebih dari 37 \\
G02 & Nyeri Kepala Berat \\
G03 & Nyeri Pada Sendi, Otot dan Tulang \\
G04 & Nyeri Pada Bagian Belakang Mata \\
G05 & Nafsu Makan Menurun \\
G06 & Mual dan Muntah \\
G07 & Kelelahan atau Lemas \\
G08 & Tekanan Darah Menurun \\
G09 & Ruam Kemerahan Sekitar 2-5 Hari Setelah Demam \\
G10 & Kerusakan Pada Pembuluh Darah dan Getah Bening \\
G11 & Pendarahan Dari Hidung, Gusi atau Di Bawah Kulit \\
G12 & Buang Air Besar Berwarna Hitam \\
G13 & Nyeri Pada Perut \\
G14 & Kegagalan Sirkulasi Saluran \\
G15 & Mulut Kering \\
G16 & Kulit Basah \& Terasa Dingin \\
G17 & Denyut Nadi Melemah \\
G18 & Sesak Nafas atau Pola Nafas Tidak Beraturan
\end{tabular}

Dibawah ini merupakan relasi atau hubungan tingkatan dengan gejala yang ada pada Demam Berdarah, hal ini dibuat bertujuan untuk menentukan tiap-tiap gejala yang ada masuk kedalam kategori tingkatan yang mana, yang bisa diperhatikan pada Tabel 3 seperti berikut.

Tabel 3. Relasi Tingkatan dengan Gejala Demam Berdarah

\begin{tabular}{|c|c|c|c|c|c|}
\hline \multirow[t]{2}{*}{ Kode } & \multirow[t]{2}{*}{ Nama Gejala } & \multicolumn{4}{|c|}{ Tingkatan } \\
\hline & & GR1 & GR2 & GR3 & GR4 \\
\hline G01 & Demam Tinggi Lebih dari $37^{\circ}$ & $\checkmark$ & $\checkmark$ & $\checkmark$ & $\checkmark$ \\
\hline G02 & Nyeri Kepala Berat & $\checkmark$ & & & \\
\hline G03 & Nyeri Pada Sendi, Otot dan Tulang & $\checkmark$ & & & \\
\hline G04 & Nyeri Pada Bagian Belakang Mata & $\checkmark$ & $\checkmark$ & & \\
\hline G05 & Nafsu Makan Menurun & $\checkmark$ & $\checkmark$ & & \\
\hline G06 & Mual dan Muntah & $\checkmark$ & $\checkmark$ & & \\
\hline G07 & Kelelahan atau Lemas & $\checkmark$ & $\checkmark$ & & $\checkmark$ \\
\hline G08 & Tekanan Darah Menurun & & $\checkmark$ & $\checkmark$ & \\
\hline G09 & Ruam Kemerahan Sekitar 2-5 Hari Setelah Demam & & & $\checkmark$ & $\checkmark$ \\
\hline G10 & Kerusakan Pada Pembuluh Darah dan Getah Bening & & & $\checkmark$ & $\checkmark$ \\
\hline G11 & Pendarahan Dari Hidung, Gusi atau Di Bawah Kulit & & & $\checkmark$ & $\checkmark$ \\
\hline G12 & Buang Air Besar Berwarna Hitam & & $\checkmark$ & & \\
\hline G13 & Nyeri Pada Perut & & $\checkmark$ & & \\
\hline G14 & Kegagalan Sirkulasi Saluran & & & $\checkmark$ & \\
\hline G15 & Mulut Kering & & & $\checkmark$ & \\
\hline G16 & Kulit Basah \& Terasa Dingin & & & & $\checkmark$ \\
\hline G17 & Denyut Nadi Melemah & & & & $\checkmark$ \\
\hline G18 & Sesak Nafas atau Pola Nafas Tidak Beraturan & & & & $\checkmark$ \\
\hline
\end{tabular}

2. Representasi Pengetahuan

Representasi pengetahuan dibuat dengan menggunakan kaidah produksi yang menampilkan bentuk pasangan antara IF dengan THEN, berikut adalah kaidah produksi yang bisa diperhatikan dalam Tabel 4 seperti berikut. 
Tabel 4. Kaidah Produksi

\begin{tabular}{cl}
\hline \hline Rule & \multicolumn{1}{c}{ Kaidah Produksi } \\
\hline 1 & IF G01 AND G02 AND G03 AND G04 AND G05 AND G06 AND G07 THEN GR1 \\
2 & IF G01 AND G04 AND G05 AND G06 AND G07 AND G08 AND G12 AND G13 \\
& THEN GR2 \\
3 & IF G01 AND G08 AND G09 AND G10 AND G11 AND G14 AND G15 THEN GR3 \\
4 & IF G01 AND G07 AND G09 AND G10 AND G11 AND G16 AND G17 AND G18 \\
& THEN GR4
\end{tabular}

\section{Certainty Factor}

Metode certainty factor dipakai untuk menghitung setiap nilai setiap gejala guna menghasilkan sebuah keputusan. Tahapan pertama yaitu dengan menentukan nilai bobot MB (tingkat keyakinan) dan MD (tingkat ketidakyakinan) dari tiap-tiap gejala yang ditentukan langsung oleh pakar pada saat wawancara yang bisa diperhatikan dalam Tabel 5 seperti berikut.

Tabel 5. Nilai MD dan MD Pada Gejala Demam Berdarah

\begin{tabular}{cclcc}
\hline \hline No & Kode & \multicolumn{1}{c}{ Nama Gejala } & MB & MD \\
\hline 1 & G01 & Demam Tinggi Lebih dari 37 & 0,7 & 0,2 \\
2 & G02 & Nyeri Kepala Berat & 0,6 & 0,4 \\
3 & G03 & Nyeri Pada Sendi, Otot dan Tulang & 0,9 & 0,2 \\
4 & G04 & Nyeri Pada Bagian Belakang Mata & 0,6 & 0,4 \\
5 & G05 & Nafsu Makan Menurun & 0,7 & 0,2 \\
6 & G06 & Mual dan Muntah & 0,6 & 0,2 \\
7 & G07 & Kelelahan atau Lemas & 0,5 & 0,2 \\
8 & G08 & Tekanan Darah Menurun & 0,7 & 0,2 \\
9 & G09 & Ruam Kemerahan Sekitar 2-5 Hari Setelah Demam & 0,8 & 0,2 \\
10 & G10 & Kerusakan Pada Pembuluh Darah dan Getah Bening & 0,5 & 0,2 \\
11 & G11 & Pendarahan Dari Hidung, Gusi atau Di Bawah Kulit & 0,8 & 0,2 \\
12 & G12 & Buang Air Besar Berwarna Hitam & 0,5 & 0,2 \\
13 & G13 & Nyeri Pada Perut & 0,6 & 0,4 \\
14 & G14 & Kegagalan Sirkulasi Saluran & 0,9 & 0,2 \\
15 & G15 & Mulut Kering & 0,6 & 0,4 \\
16 & G16 & Kulit Basah \& Terasa Dingin & 0,7 & 0,2 \\
17 & G17 & Denyut Nadi Melemah & 0,7 & 0,2 \\
18 & G18 & Sesak Nafas atau Pola Nafas Tidak Beraturan & 0,7 & 0,2
\end{tabular}

Setelah mendapatkan nilai bobot MD dan MD, tahapan selanjutnya ialah menghitung nilai CF dari tiap-tiap gejala dengan menggunakan rumus dibawah ini, dan hasil dari perhitungan nilai CF bisa diperhatikan pada Tabel 6 seperti berikut.

Dimana :

$$
C F[H, E]=M B[H, E]-M D[H, E]
$$

CF : Faktor Kepastian

$\mathrm{MB}[\mathrm{H}, \mathrm{E}]$ : Nilai Tingkat Kepercayaan terhadap hipotesis H yang dipengaruhi evidence (E).

$\mathrm{MD}[\mathrm{H}, \mathrm{E}]$ : Nilai Ketidakpercayaan terhadap hipotesis $\mathrm{H}$ yang dipengaruhi evidence $(\mathrm{E})$.

Tabel 6. Hasil Perhitungan Nilai CF

\begin{tabular}{|c|c|c|c|c|c|c|}
\hline \multirow{2}{*}{ No } & \multirow{2}{*}{ Kode } & \multirow{2}{*}{ Nama Gejala } & \multicolumn{4}{|c|}{ Tingkatan } \\
\hline & & & GR1 & GR2 & GR3 & GR4 \\
\hline 1 & G01 & Demam Tinggi Lebih dari $37^{\circ}$ & 0,5 & 0,5 & 0,5 & 0,5 \\
\hline 2 & G02 & Nyeri Kepala Berat & 0,2 & - & - & - \\
\hline 3 & G03 & Nyeri Pada Sendi, Otot dan Tulang & 0,7 & - & - & - \\
\hline 4 & G04 & Nyeri Pada Bagian Belakang Mata & 0,2 & 0,2 & - & - \\
\hline 5 & G05 & Nafsu Makan Menurun & 0,5 & 0,5 & - & - \\
\hline 6 & G06 & Mual dan Muntah & 0,4 & 0,4 & - & - \\
\hline 7 & G07 & Kelelahan atau Lemas & 0,3 & 0,3 & - & 0,3 \\
\hline 8 & G08 & Tekanan Darah Menurun & - & 0,5 & 0,5 & - \\
\hline 9 & G09 & Ruam Kemerahan Sekitar 2-5 Hari Setelah Demam & - & - & 0,6 & 0,6 \\
\hline 10 & G10 & Kerusakan Pada Pembuluh Darah dan Getah Bening & - & - & 0,3 & 0,3 \\
\hline
\end{tabular}




$\begin{array}{llcccc}\text { G11 } & \text { Pendarahan Dari Hidung, Gusi atau Di Bawah Kulit } & - & - & 0,6 & 0,6 \\ \text { G12 } & \text { Buang Air Besar Berwarna Hitam } & - & 0,3 & - & - \\ \text { G13 } & \text { Nyeri Pada Perut } & - & 0,2 & - & - \\ \text { G14 } & \text { Kegagalan Sirkulasi Saluran } & - & - & 0,7 & - \\ \text { G15 } & \text { Mulut Kering } & - & - & 0,2 & - \\ \text { G16 } & \text { Kulit Basah \& Terasa Dingin } & - & - & - & 0,5 \\ \text { G17 } & \text { Denyut Nadi Melemah } & - & - & - & 0,5 \\ \text { G18 } & \text { Sesak Nafas atau Pola Nafas Tidak Beraturan } & - & - & - & 0,5\end{array}$

Kemudian setelah mendapatkan nilai CF dari tiap-tiap gejala, dilanjutkan dengan melakukan sebuah perhitungan CF Combine yang bisa dilihat berikut ini :

1. Grade 1

$$
\begin{aligned}
\mathrm{CF} & =\mathrm{CF} 1+\mathrm{CF} 2 *[1-(\mathrm{CF} 1)] \\
& =0,5+0,2 *[1-0,5] \\
& =0,60 \\
\mathrm{CF} 2 & =\mathrm{CF} 2+\mathrm{CF} 3 *[1-(\mathrm{CF} 2)] \\
& =0,60+0,7 *[1-0,60] \\
& =0,88 \\
\mathrm{CF} 3 & =\mathrm{CF} 3+\mathrm{CF} 4 *[1-(\mathrm{CF} 3)] \\
& =0,88+0,2 *[1-0,88] \\
& =0,904 \\
\mathrm{CF} 4 & =\mathrm{CF} 4+\mathrm{CF} 5 *[1-(\mathrm{CF} 4)] \\
& =0,904+0,5 *[1-0,904] \\
& =0,952 \\
\mathrm{CF} 5 & =\mathrm{CF} 5+\mathrm{CF} 6 *[1-(\mathrm{CF} 5)] \\
& =0,952+0,4 *[1-0,952] \\
& =0,971 \\
\mathrm{CF} 6 & =\mathrm{CF} 6+\mathrm{CF} 7 *[1-(\mathrm{CF} 6)] \\
& =0,971+0,3 *[1-0,971] \\
& =0,979
\end{aligned}
$$

Maka diperoleh hasil pada Grade 1 sebesar $0,979(0,98)$ atau sebesar $98 \%$.
2. Grade 2

$$
\begin{aligned}
\mathrm{CF} & =\mathrm{CF} 1+\mathrm{CF} 2 *[1-(\mathrm{CF} 1)] \\
& =0,5+0,2 *[1-0,5] \\
& =0,60 \\
\mathrm{CF} 2 & =\mathrm{CF} 2+\mathrm{CF} 3 *[1-(\mathrm{CF} 2)] \\
& =0,60+0,5 *[1-0,60] \\
& =0,80 \\
\mathrm{CF} 3 & =\mathrm{CF} 3+\mathrm{CF} 4 *[1-(\mathrm{CF} 3)] \\
& =0,80+0,4 *[1-0,80] \\
& =0,88 \\
\mathrm{CF} 4 & =\mathrm{CF} 4+\mathrm{CF} 5 *[1-(\mathrm{CF} 4)] \\
& =0,88+0,3 *[1-0,88] \\
& =0,916 \\
\mathrm{CF} 5 & =\mathrm{CF} 5+\mathrm{CF} 6 *[1-(\mathrm{CF} 5)] \\
& =0,916+0,5 *[1-0,916] \\
& =0,958 \\
\mathrm{CF} 6 & =\mathrm{CF} 6+\mathrm{CF} 7 *[1-(\mathrm{CF} 6)] \\
& =0,958+0,3 *[1-0,958] \\
& =0,971 \\
\mathrm{CF} 7 & =\mathrm{CF} 7+\mathrm{CF} 8 *[1-(\mathrm{CF} 7)] \\
& =0,971+0,2 *[1-0,971] \\
& =0,977
\end{aligned}
$$

Maka diperoleh hasil pada Grade 2 sebesar $0,977(0,98)$ atau sebesar $98 \%$.

3. Grade 3

$$
\begin{aligned}
\mathrm{CF} & =\mathrm{CF} 1+\mathrm{CF} 2 *[1-(\mathrm{CF} 1)] \\
& =0,5+0,5^{*}[1-0,5] \\
& =0,75 \\
\mathrm{CF} 2 & =\mathrm{CF} 2+\mathrm{CF} 3 *[1-(\mathrm{CF} 2)] \\
& =0,75+0,6 *[1-0,75] \\
& =0,90 \\
\mathrm{CF} 3 & =\mathrm{CF} 3+\mathrm{CF} 4 *[1-(\mathrm{CF} 3)] \\
& =0,90+0,3 *[1-0,90] \\
& =0,93 \\
\mathrm{CF} 4 & =\mathrm{CF} 4+\mathrm{CF} 5 *[1-(\mathrm{CF} 4)] \\
& =0,93+0,6 *[1-0,93] \\
& =0,972 \\
\mathrm{CF} 5 & =\mathrm{CF} 5+\mathrm{CF} 6 *[1-(\mathrm{CF} 5)] \\
& =0,972+0,7 *[1-0,972] \\
& =0,991 \\
\mathrm{CF} 6 & =\mathrm{CF} 6+\mathrm{CF} 7 *[1-(\mathrm{CF} 6)] \\
& =0,991+0,2 *[1-0,991] \\
& =0,992
\end{aligned}
$$

4. Grade 4

$$
\begin{aligned}
\mathrm{CF} & =\mathrm{CF} 1+\mathrm{CF} 2 *[1-(\mathrm{CF} 1)] \\
& =0,5+0,3 *[1-0,5] \\
& =0,65 \\
\mathrm{CF} 2 & =\mathrm{CF} 2+\mathrm{CF} 3 *[1-(\mathrm{CF} 2)] \\
& =0,65+0,6 *[1-0,65] \\
& =0,86 \\
\mathrm{CF} 3 & =\mathrm{CF} 3+\mathrm{CF} 4 *[1-(\mathrm{CF} 3)] \\
& =0,86+0,3 *[1-0,86] \\
& =0,902 \\
\mathrm{CF} 4 & =\mathrm{CF} 4+\mathrm{CF} 5 *[1-(\mathrm{CF} 4)] \\
& =0,902+0,6 *[1-0,902] \\
& =0,96 \\
\mathrm{CF} 5 & =\mathrm{CF} 5+\mathrm{CF} 6 *[1-(\mathrm{CF} 5)] \\
& =0,96+0,5 *[1-0,96] \\
& =0,98 \\
\mathrm{CF} 6 & =\mathrm{CF} 6+\mathrm{CF} 7 *[1-(\mathrm{CF} 6)] \\
& =0,98+0,5 *[1-0,98] \\
& =0,99 \\
\mathrm{CF} 7 & =\mathrm{CF} 7+\mathrm{CF} 8 *[1-(\mathrm{CF} 7)]
\end{aligned}
$$


Maka diperoleh hasil pada Grade 3 sebesar $0,992(0,99)$ atau sebesar $99 \%$.

$$
\begin{aligned}
& =0,99+0,5 *[1-0,99] \\
& =0,995
\end{aligned}
$$

Maka diperoleh hasil pada Grade 4 sebesar 0,995 atau sebesar $99 \%$.

\subsection{Implementasi Sistem}

Tahapan selanjutnya ialah tahapan implementasi yang menghasilkan sebuah sistem pendukung keputusan dalam mendiagnosa Demam Berdarah berbasis website kedalam program perangkat lunak dengan memakai bahasa pemrograman PHP \& MySQL, yang bisa diamati pada Gambar berikut ini.

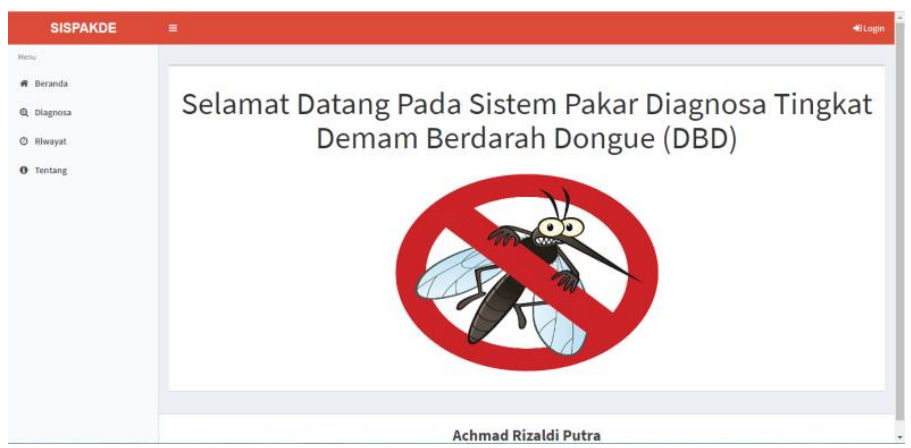

Gambar 2. Implementasi Halaman Utama

Gambar 2 diatas menunjukkan sebuah tampilan halaman utama pada pengguna yang akan menyajikan keseluruhan menu yang ada dan dapat dipakai oleh pengguna.

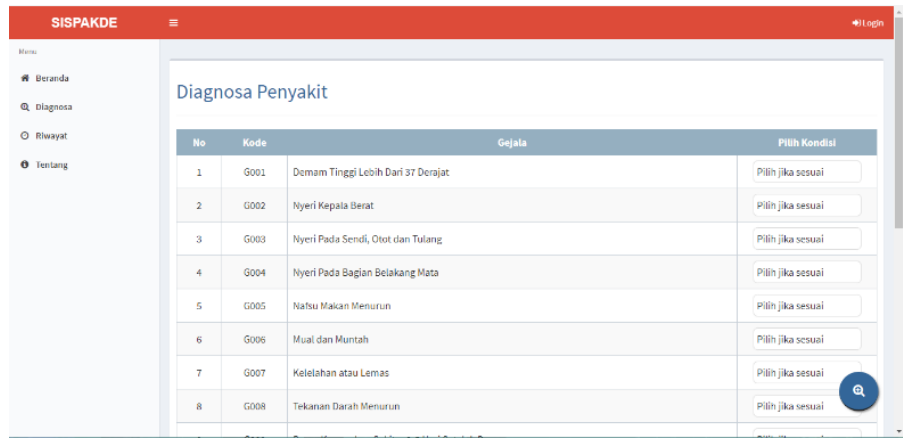

Gambar 3. Implementasi Menu Diagnosa atau Konsultasi

Gambar 3 diatas menunjukkan tampilan halaman menu diagnosa yang dimana pengguna bisa memulai diagnosa atau konsultasi dengan dihadapkan beberapa pertanyaan berupa gejala yang sedang dirasakan saat ini.

\subsection{Pengujian}

Tahapan pengujian dilaksanakan untuk mendapati sistem yang dibuat apakah sudah sesuai dan tidak terdapat kesalahan. Berikut merupakan hasil yang diperoleh dari pengujian dengan memakai Black Box Testing.

Tabel 7. Pengujian Halaman Utama

\begin{tabular}{ccccc}
\hline \hline No & Kondisi Awal & $\begin{array}{c}\text { Kondisi Yang } \\
\text { Diharapkan }\end{array}$ & Kondisi Hasil & Hasil Uji \\
\hline Menampilkan Halaman & $\begin{array}{c}\text { Sistem menampilkan } \\
\text { halaman utama yang } \\
\text { terdiri dari beberapa } \\
\text { Utama }\end{array}$ & Sesuai Harapan & Diterima \\
2 & Memilih Menu Diagnosa & Sistem menampilkan & Sesuai Harapan & Diterima
\end{tabular}


halaman untuk melakukan diagnosa

Sistem menampilkan halaman riwayat

Sistem menampilkan halaman tentang
Sesuai Harapan Diterima

Sesuai Harapan Diterima

$4 \quad$ Memilih Menu Tentang

Pada Tabel 7 diatas menunjukkan bahwa semua kondisi yang diujikan sesuai dengan harapan.

Tabel 8. Pengujian Menu Diagnosa

\begin{tabular}{|c|c|c|c|c|}
\hline No & Kondisi Awal & $\begin{array}{c}\text { Kondisi Yang } \\
\text { Diharapkan }\end{array}$ & Kondisi Hasil & Hasil Uji \\
\hline 1 & Memilih Menu Diagnosa & $\begin{array}{l}\text { Sistem menampilkan } \\
\text { halaman untuk } \\
\text { melakukan diagnosa }\end{array}$ & Sesuai Harapan & Diterima \\
\hline 2 & $\begin{array}{l}\text { User memilih gejala atau } \\
\text { kondisi yang dirasakan }\end{array}$ & $\begin{array}{c}\text { Sistem menampilkan } \\
\text { pertanyaan gejala } \\
\text { dengan beberapa opsi } \\
\text { jawaban }\end{array}$ & Sesuai Harapan & Diterima \\
\hline 3 & Klik hasil diagnosa & $\begin{array}{l}\text { Sistem menampilkan } \\
\text { hasil diagnosa }\end{array}$ & Sesuai Harapan & Diterima \\
\hline
\end{tabular}

Pada Tabel 8 diatas menunjukkan bahwa semua kondisi yang diujikan sesuai dengan harapan.

\subsection{Dokumentasi}

Pada tahap dokumentasi ini ialah tahapan dimana menjelaskan bagaimana cara sistem bekerja atau dioperasikan. Sebagai contoh, dibawah ini terdapat hasil setelah pengguna melakukan diagnosa atau konsultasi dengan menjawab pertanyaan seputar gejala yang bisa diperhatikan pada Gambar 4 dan 5 yang tertera seperti dibawah berikut ini.

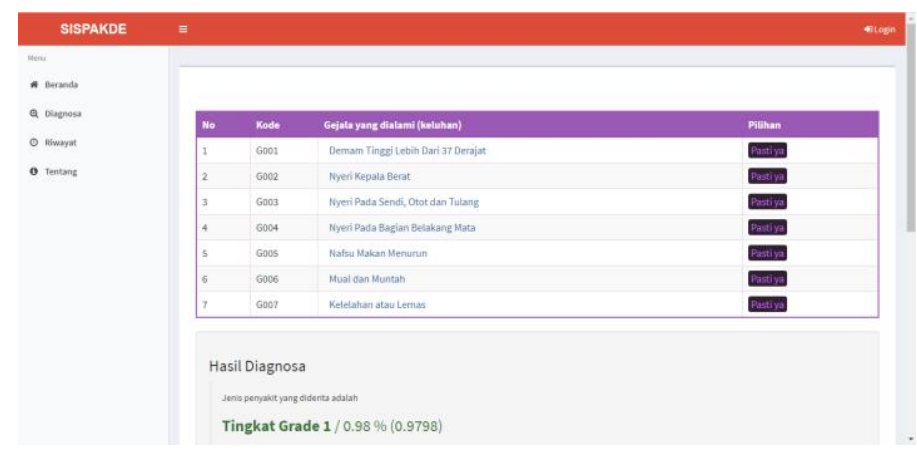

Gambar 4. Halaman Hasil Diagnosa

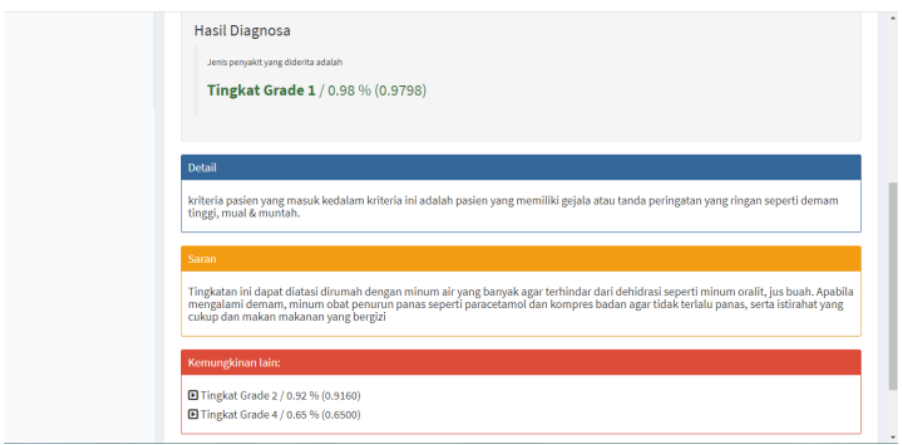

Gambar 5. Halaman Hasil Diagnosa (lanjutan) 
Gambar 4 \& 5 diatas membuktikan hasil dari proses diagnosa ketika ada pengguna yang menggunakan atau mengoperasikan sistem untuk melakukan diagnosa atau konsultasi dengan informasi yang berisi gejala yang dipilih oleh pengguna ketika melakukan proses diagnosa, kemudian akan diberikan informasi terkait masuk kedalam kategori yang mana dengan disertain dengan nilai tingkat kepercayaan nya, kemudian akan diberikan detail dari tingkatan yang diderita oleh pengguna, lalu terdapat saran yang harus dilakukan oleh pengguna yang disesuaikan berdasarkan tingkatan yang dialami dan terdapat hasil kemungkinan lain pengguna masuk kedalam kategori tingkatan yang lainnya.

\section{SIMPULAN}

Berdasarkan penelitian yang telah dilaksanakan pada pembuatan sistem pendukung keputusan guna mendiagnosa tingkat Demam Berdarah memakai metode Certainty Factor bisa kita simpulkan berikut ini :

1. Sistem pendukung keputusan yang dibangun ini mampu memberikan informasi tingkat Demam Berdarah beserta dengan nilai persentase tingkat kepercayaan dan memberikan solusi yang harus dilakukan.

2. Implementasi metode certainty factor tentunya sangat membantu dalam membuktikan tingkat Demam Berdarah dikarenakan hasil dari implementasi metode ini berupa persentase untuk menggambarkan tingkat keyakinan dari seorang ahli dalam mendiagnosa tingkat Demam Berdarah.

3. Metode certainty factor cocok dipakai dalam membuat sistem pendukung keputusan yang memiliki gejala dan hasil yang tidak pasti.

\section{SARAN}

Dari hasil penelitian yang dilakukan maka terdapat beberapa saran atau masukan untuk penelitian selanjutnya yang bertujuan untuk pengembangan atau penyempurnaan pada penelitian selanjutnya diantaranya ialah diperlukan adanya perbandingan dengan metode lain selain certainty factor agar dapat menentukan metode yang terbaik dalam membantu pembuatan sistem pendukung keputusan, dan juga dapat dikembangkan menggunakan platform android.

\section{DAFTAR PUSTAKA}

[1] N. Sunaryo, Y. Yunus \& Sumijan, "Sistem Pakar Menggunakan Metode Certainty Factor dalam Identifikasi Pengembangan Minat dan Bakat Khusus pada Siswa (Studi Kasus di SMA Muhammadiyah 1 Padang)”, Jurnal Sistim Informasi dan Teknologi, vol. 3, no. 2, pp. 48-55, 2021.

[2] A. F. Indriani, E. Y. Rachmawati \& J. D. Fitriana, "Pemanfaatan Metode Certainty Factor dalam Sistem Pakar Diagnosa Penyakit pada Anak", Tchno.COM, vol. 17, no. 1, pp. 12-22, 2018.

[3] M. N. Assyifa, “Aplikasi Sistem Pakar Berbasis Android Untuk Diagnosis Penyakit Gastroesophageal Reflux Disease (GERD) Dengan Metode Certainty Factor”, Jurnal Ilmiah Teknologi dan Rekayasa, vol. 24, no. 2, pp. 78-90, 2019.

[4] Rokom, "Data Kasus Terbaru DBD di Indonesia", Kementerian Kesehatan Republik Indonesia (Kemenkes RI), 20 januari 2021, [Online]. Available: https://sehatnegeriku.kemkes.go.id/baca/umum/20201203/2335899/data-kasus-terbaru-dbdindonesia/. [Diakses: 22 Mei 2021].

[5] N. K. Ariasih \& I. W. D. Suryawan, "Implementasi Metode Certainty Factor Untuk Diagnosa Penyakit Mata Merah Visus Turun pada Manusia”, SINTESA, pp. 187-196, 2020.

[6] W. Yulianti, L. Trisnawati \& T. Manullang, "Sistem Pakar Dengan Metode Certainty Factor Dalam Penentuan Gaya Belajar Anak Usia Remaja", Jurnal Teknologi Informasi \& Komunikasi Digital Zone, vol. 10, no. 2, pp. 120-130, 2019. 
[7] Aditiawarman, H. Nasution \& Tursina, "Sistem Pakar Pendeteksi Penyakit Mata Berbasis Android", Jurnal Sistem dan Teknologi Informasi (JUSTIN), vol. 5, no. 2, pp. 118-122, 2017.

[8] B. Pratama \& J. R. Sagala, "Sistem Pakar Mendiagnosa Penyakit Demam Berdarah Akibat Virus Nyamuk Aedes Aegpty Dengan Menggunakan Metode Certainty Factor”, Excellent Midwifery Journal, vol. 2, no. 2, pp. 68-73, 2019.

[9] D. Pribadi, S. Athiry, R. A. Saputra, A. Supiandi \& D. Prayudi, "Sistem Pakar Diagnosa Penyakit Demam Berdarah Dengue Menggunakan Algoritma Iterative Dichotosimer 3 (ID3)", Seminar Nasional Inovasi dan Tren (SNIT), pp. 129-133, 2018.

[10] S. Lestanti, S. Kirom, \& D. Kustiari, "Penerapan Metode Forward Chaining Pada Perancangan Sistem Pakar Diagnosis Awal Demam Berdarah”, Jurnal Antivirus, vol. 11, no. 2, pp. 134-142, 2017.

[11] R. Y. Aldiansyah, "Sistem Pakar Diagnosa Penyakit Demam Berdarah Dengue Menggunakan Metode Backward Chaining Berbasis Android (Studi Kasus Klinik Pratama Sartika 77)", Ubiquitous: Computers and It's Applications Journal, vol. 3, no. 1, pp. 27-34, 2020.

[12] Y. E. Windarto, R. R. Isnanto \& A. Setiawan, "Sistem Pakar Diagnosis Penyakit Gastritis Menggunakan Metode Certainty Factor Berbasis Android”, TRANSFORMATIKA, vol. 18, no. 1 , pp. 36-55, 2020.

[13] T. Junaidi \& Y. Yunus, "Sistem Pakar dengan Metode Certainty Factor dalam Analisis Penyakit Herpes Zoster pada Manusia”, Jurnal Informasi dan Teknologi, vol. 3, no. 2, pp. 58 $-65,2021$.

[14] W. U. Setiabudi, E. Sugiharti \& F. Y. Arini, "Expert System Diagnosing Dental Disease Using Certainty Factor Method", Scientific Journal of Informatics, vol. 4, no. 1, pp. 43-50, 2017.

[15] R. Pane, A. A. Ritonga, B. Bangun, I. Purnama \& S. D. Raharjo, "Expert System of Diagnosing Chikungunya Disease by Certainty Factor Method”, Jurnal Mantik, vol. 4, no. 3, pp. 2035-2040, 2020.

[16] N. A. Hasibuan, H. Sunandar, S. Alas \& Suginam, "Sistem Pakar Mendiagnosa Penyakit Kaki Gajah Menggunakan Metode Certainty Factor”, Jurnal Riset Sistem Informasi dan Teknik Informatika (JURASIK), vol. 2, no. 1, pp. 29-39, 2017.

[17] Y. M. Idah, M. D. Fatimah, \& D. P. Hutomo, “ Pemanfaatan Teknologi Informasi Dengan Menggunakan Sistem Pakar di Bidang Kedokteran”, Jurnal CITISEE, pp. 154-161, 2017.

[18] I. M. Fadhil, D. D. S. Fatimah \& D. Kurniadi, "Perancangan Aplikasi Sistem Pakar Untuk Diagnosis Penyakit Pada Ikan Cupang dengan Metode Naive Bayes", Jurnal Algoritma, vol. 16, no. 02, pp. 255-262, 2019.

[19] E. D. Sri Mulyani, C. R. Hidayat \& T. C. Ulfa, "Sistem Pakar Untuk Menentukan Jurusan Kuliah Berdasarkan Minat dan Bakat Siswa SMA Dengan Menggunakan Metode Forward Chaining", CSRID Journal, vol. 10, no. 2, pp. 80-92, 2018.

[20] A. Saepulloh \& D. D. S. Fatimah, "Pengembangan Sistem Pakar Diagnosis Penyakit dan Hama Pada Tanaman Padi Varietas Sarinah Berbasis Android", Jurnal Algoritma Sekolah Tinggi Teknologi Garut, vol. 13, no. 1, pp. 149-156, 2016. 